\title{
Evaluation and Mapping of The Use of Technology in The Pulp and Paper Agro Industry
}

\author{
Yulia Nurendah ${ }^{\#}$ \\ \# STIE Kesatuan Bogor, Jl Ranggagading 1 Bogor, 16123, Indonesia \\ E-mail: lia_niceone@yahoo.com
}

\begin{abstract}
The execution and the implementation of the revitalization program and the growth of pulp and paper agro industry require evaluation activities. For that, we need a study that will provide evaluation and mapping of the implementation of policies and programs so that the analysis, assessment and weighting can be more transparent and measurable. The main objective of this activity is, there are an evaluation and mapping policy as well as output-based programs to the use of technology in the pulp and paper agro industry in 2010-2012 and the functioning of the evaluation program results and policies as a policy formulation and program for 2015-2019. Generally, the data analysis methods used are Descriptive Analysis Method, Assessment Technology, Counting Technology Index, Technology Mapping: Importance Performance Analysis, Benchmarking, SWOT Analysis, RIA (Regulatory Impact Analysis). The technology used in the pulp and paper agro industries in Indonesia has generally been good in the downstream sector. The results of the overall analysis show that the type of technology used is still dominant with 'semi-mechanical technology'. The status of the use of technology in pulp industry is good, while the status of the use of technology in paper industry is very good.
\end{abstract}

Keywords - evaluation, use, mapping, pulp, and paper.

\section{INTRODUCTION}

\section{A. Background}

The execution and the implementation of the revitalization program and the growth of agro industry require an evaluation activity. The evaluation of policy and the program of technology used in agro industry are important activities to determine the level of success that has been achieved, to realize that the program targets have not been achieved by identifying the existing problems, and to prepare formulation materials, recommendation of policies and better programs in the future. For that, we need a study that will provide evaluation and mapping of the implementation of policies and programs so that the analysis, assessment and weighting can be more transparent and measurable.

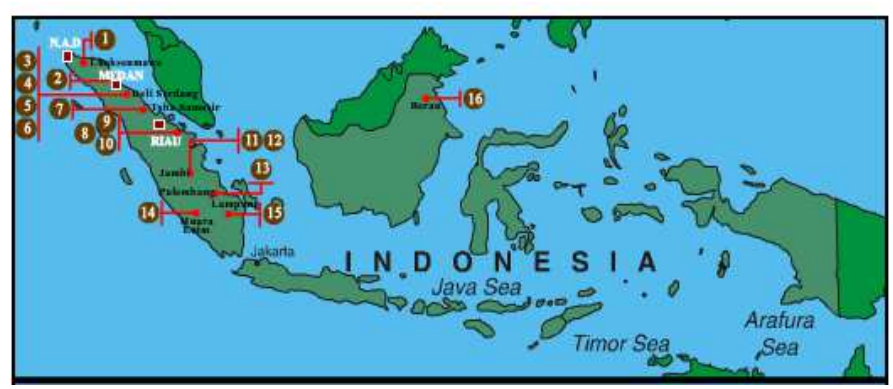

Fig.1. Distribution of Paper Industry in Sumatra and Kalimantan Islands

\section{B. Purposes of Research}

The main purpose of this activity is, there are evaluation and policy mapping as well as output-based programs to the use of technology in the pulp and paper agro industry in 2010-2012 and the functioning of the results of the program evaluation and policy as a policy formulation and program for 2015 - 2019. More to be shown in Fig. 1 and 2.

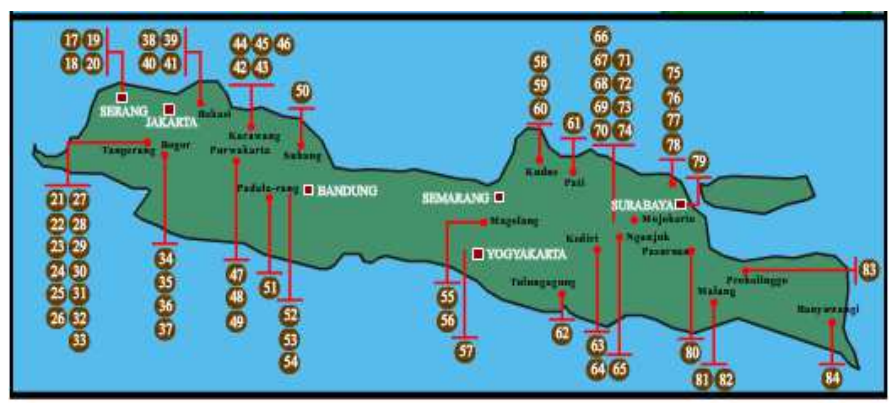

Fig.2. Distribution of Paper Industry in Java Island

\section{RESEARCH METHODOLOGY}

\section{A. Framework of Activities}




\section{B. Concept Approach}

- 1. Basic Technology Assessment Principles

- 2. Technology Adoption

\section{Methodology}

Generally, the data analysis methods used are descriptive analysis, Assessment Technology, Counting technology Index, Technology Mapping: Importance Performance Analysis, Benchmarking, SWOT Analysis, RIA (Regulatory Impact Analysis).

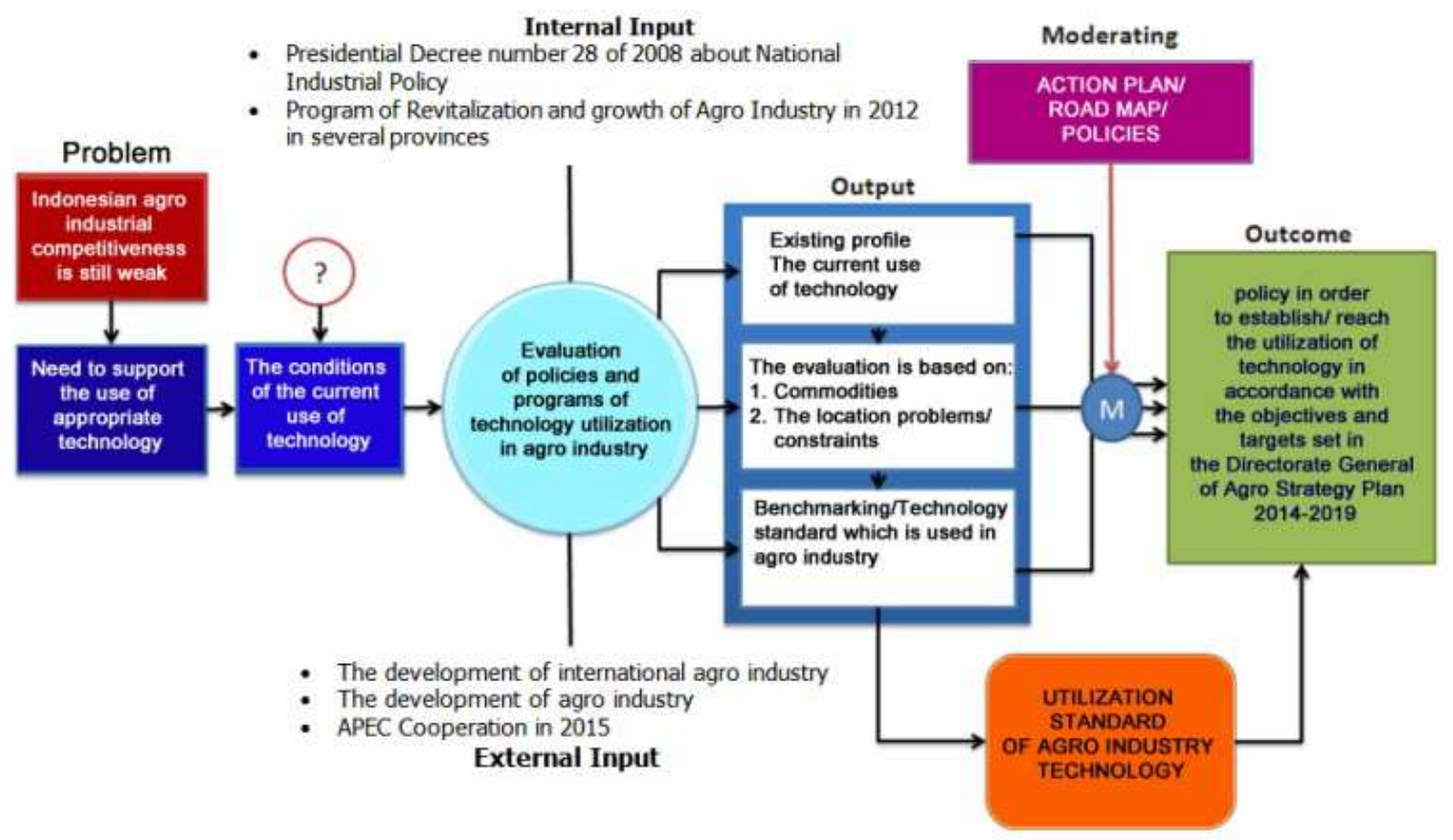

Fig 3. Framework of Evaluation Policy Activity and Technology Utilization Program in Agro Industry

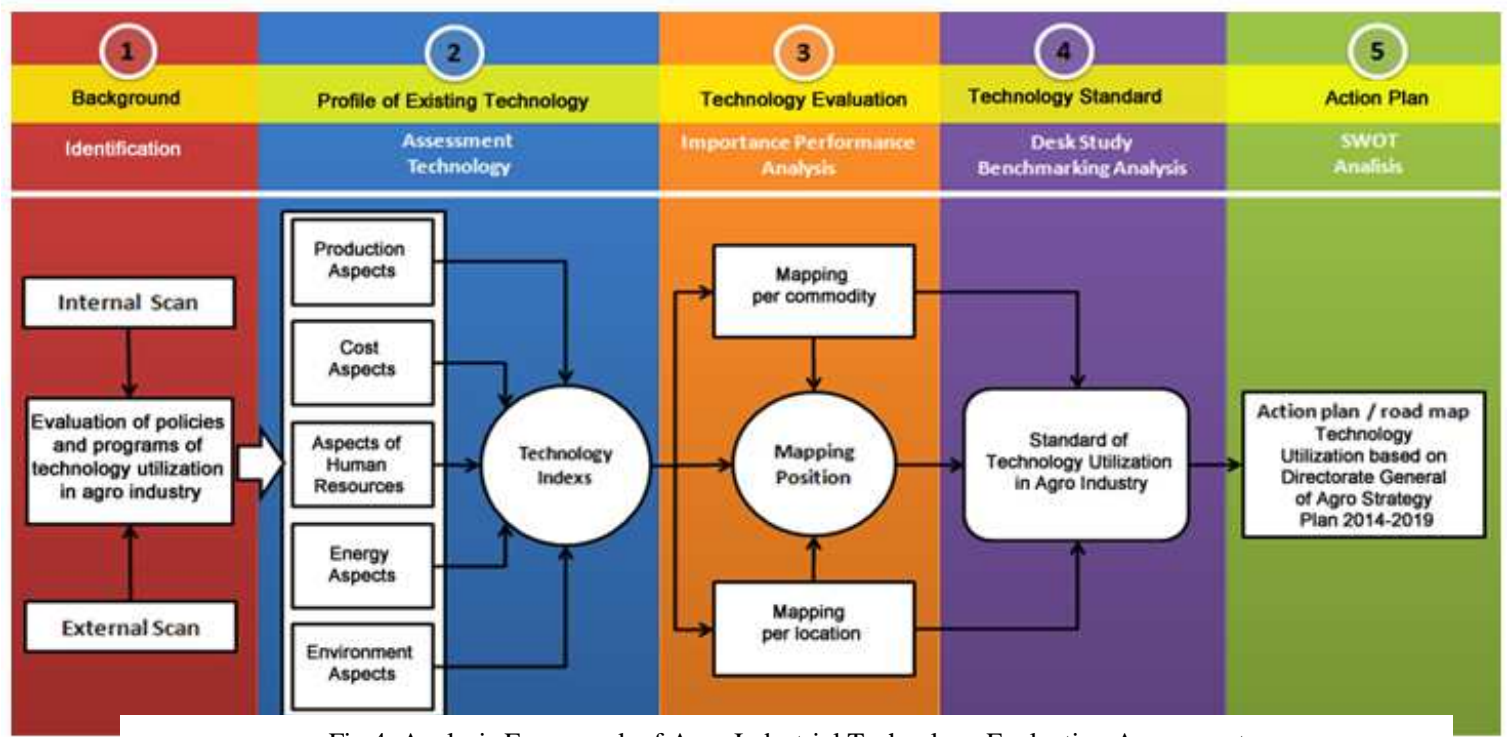

Fig 4. Analysis Framework of Agro Industrial Technology Evaluation Assessment 


\section{RESULTS AND DISCUSSIONS}

\section{A. Map of Industrial Technology}

Indonesia is one of the major producers of pulp and paper world. In 2011, Indonesia is the largest paper producer 12th world with a share of 2.2 percent of total world production which reached 350 million tons. As for the pulp production, Indonesia was ranked 9th world with a share of 2.5 percent of the total world production of 200 million tonnes

TABLE I

StREAM DEVELOPMENT OF PULP AND PAPER INDUSTRY IN INDONESIA

\begin{tabular}{|l|l|l|}
\hline Stream & Industry Groups & Commercial Products \\
\hline Up Stream & Pulp Mill & $\begin{array}{l}\text { Kraft Pulp } \\
\text { Soda Pulp }\end{array}$ \\
\hline Mid Stream & Paperboard Mills & $\begin{array}{l}\text { Medium Liner Paper } \\
\text { Kraft Liner Paper }\end{array}$ \\
\hline Down Stream & Paper Mills & Corrugated board box paper \\
& & Tissue Paper \\
& & HVS Paper \\
& & Book Paper \\
& & Cigarette Paper \\
& & Valuable Paper \\
& & Art Paper \\
& & News Print \\
& & Specialty Paper \\
\hline
\end{tabular}

Technology Evaluation of Pulp Up Stream Industry

TABLE II

INDEX OF TECHNOLOGY UTILIZATION IN PULP UP STREAM INDUSTRY

\begin{tabular}{|l|l|l|}
\hline Aspect of Assessment & Assessment Index & Information \\
\hline Production Technology & 6.3158 & \\
\hline Energy & 2.1053 & \\
\hline Environment & 1.2895 & \\
\hline Human Resources & 1.9737 & \\
\hline Costs of Production & 2.9474 & \\
\hline Research & 0.8421 & \\
\hline Final Index & 15.4737 & \\
\hline Utilization Status & Medium Level & More than 15 \\
\hline
\end{tabular}

TABLE III

INDEX OF TECHNOLOGY UTILIZATION IN MEDIUM CARTON INDUSTRY

\begin{tabular}{|l|l|l|}
\hline Aspect of Assessment & Assessment Index & Information \\
\hline Production Technology & 8.4211 & \\
\hline Energy & 2.1053 & \\
\hline Environment & 2.3947 & \\
\hline Human Resources & 1.9737 & \\
\hline Costs of Production & 4.4211 & \\
\hline Research & 1.2632 & \\
\hline Final Index & 20.5789 & More than 20 \\
\hline Utilization Status & High Level & \\
\hline
\end{tabular}

TABLE IV

INDEX OF TECHNOLOGY UTILIZATION IN PAPER DOWN STREAM INDUSTRY

\begin{tabular}{|l|l|c|}
\hline Aspect of Assessment & Assessment Index & Information \\
\hline Production Technology & 8.9474 & \\
\hline Energy & 2.1053 & \\
\hline Environment & 2.5789 & \\
\hline Human Resources & 1.9737 & \\
\hline Costs of Production & 4.4211 & \\
\hline Research & 1.2632 & \\
\hline Final Index & 21.2895 & More than 20 \\
\hline Utilization Status & High Level & \\
\hline
\end{tabular}

The Development Strategy of Agro Industrial Technology of Pulp and Paper
TABLE V

DetaILS OF OPERATIONAL STRATEgy OF AgRo Industrial TeChNOLOGy DEVELOPMENT IN THE PULP AND PAPER

\begin{tabular}{|c|c|}
\hline Operational Strategy & Action Plan \\
\hline $\begin{array}{l}\text { Strengthening } \\
\text { Industry and } \\
\text { Industry } \\
\text { Performance }\end{array}$ & $\begin{array}{l}\text { 1. Increasing the mastery of technology in } \\
\text { the pulp and paper industry, especially } \\
\text { in the field of engineering } \\
\text { 2. Increasing the mastery of the } \\
\text { engineering machinery in the pulp and } \\
\text { paper industry, especially in the term of } \\
\text { purification }\end{array}$ \\
\hline $\begin{array}{l}\text { Diversification of } \\
\text { Derivative Products } \\
\text { / New Commercial } \\
\text { Products }\end{array}$ & $\begin{array}{l}\text { 1. Technology development of } \\
\text { manufacturing pulp products, especially } \\
\text { hardwood kraft pulp } \\
\text { 2. Technology Development of advanced } \\
\text { paper as plastic replacement } \\
\text { 3. Technology Development of pulp and } \\
\text { paper waste utilization production, } \\
\text { especially waste water treatment plant } \\
\text { (IPAL) oreffluent treatment plant (ETP) } \\
\text { with integrated clarifier and aeration } \\
\text { basin as the development of the latest } \\
\text { technology for waste treatment }\end{array}$ \\
\hline $\begin{array}{l}\text { Improvement of } \\
\text { Human Resources }\end{array}$ & $\begin{array}{l}\text { 1. Improving the engineering mastery of } \\
\text { treatment technology } \\
\text { 2. Technology training }\end{array}$ \\
\hline $\begin{array}{l}\text { Government } \\
\text { Policies }\end{array}$ & $\begin{array}{l}\text { 1. The implementation of Origine et } \\
\text { Legalite des Bois (OLB), PEFC COC, } \\
\text { Hongkong Green Label Certificate, } \\
\text { Timber Legality Verification System } \\
\text { (SVLK). OHSAS 18001:2007 (Safety } \\
\text { System), ISO 14001:2004 } \\
\text { (Environmental Management System), } \\
\text { and ISO 9001:2008 (Quality } \\
\text { Management System). ISO } 14025 \\
\text { (green label) } \\
\text { 2. Providing education and training } \\
\text { 3. Incentives for the procurement of } \\
\text { technology / machinery and equipment } \\
\text { 4. Incentives for taxation in the form of } \\
\text { tax allowance and tax holiday for pulp } \\
\text { and paper industry }\end{array}$ \\
\hline $\begin{array}{l}\text { Strengthening } \\
\text { Research and } \\
\text { Development Roles }\end{array}$ & $\begin{array}{l}\text { 1. Increasing the research funding } \\
\text { especially more modern and efficient } \\
\text { pulp and paper processing } \\
\text { 2. Encouraging industrial research } \\
\text { institute }\end{array}$ \\
\hline Financing & $\begin{array}{l}\text { Facilitating the procurement of machinery } \\
\text { and equipment loans }\end{array}$ \\
\hline
\end{tabular}

\section{CONCLUSION}

Technologies used in Agro Industries of pulp and paper industry in Indonesia has generally been good in the downstream sector.

Overall analysis results indicate that the type of technology used is still dominant with 'semi-mechanical 
technology. The status of pulp industrial technology use has been good, while the status of the utilization of paper industrial technology is very good.

\section{REFERENCES}

[1] Bapedal. 1998. Rencana Pelaksanaan Produksi Bersih. Booklet Badan Pengendalian Dampak Lingkungan. Jakarta.
[2] Casey. 1981.Pulp and Paper Chmistry and Chemical Technology, Vol III. John Willey and Sons inc. New York.

[3] Gustiawan. 2002. Studi Potensi Aplikasi Produksi Bersih di Industri Pulp dan Kertas. Skripsi. Institut Pertanian Bogor

[4] Hanif. 2008 Mempelajari Aspek Teknologi Pulp dan Kertas. Laporan Praktek Lapang. Institut Pertanian Bogor.

[5] Nurendah, Y. 2014. Evaluasi dan Pemetaan Pemanfaatan Teknologi Pada Industri Agro. Departemen Perindustrian

[6] Perry. 1999. Chemical Engineering Handbook. 7th edition. New York.

[7] Thorp. 1991. Pulp and Paper Manufacture. Paper Machine Operation. 3rd edition volume 1. John Willey and Sons inc. Singapore 